\title{
II. FREE COMMUNICATIONS
}

\author{
DISTENSIBILITY OF THE VEIN: FROM THE ARCHITECTURAL POINT OF VIEW
}

\author{
Takehiko Azuma and Masamitsu Hasegawa
}

Department of Physiology, Shinshu University Medical School, Matsumoto, Japan

BY MEANS of a universal tensile testing instrument, stress-strain relationships were studied on longitudinal and circumferential strips excised from various portions of the caval vein and from the cervical, axillary, iliac and femoral veins of dogs. In order to investigate the mechanical properties from the architectural point of view, the relationships were also studied on the nuchal ligament, tendon and intestinal smooth muscle bundle which are composed mainly of elastin, collagen and smooth muscle fibers, respectively. Histological examinations were also carried out with these vascular and non-vascular specimens.

The results obtained were summarized as follows: (1) the circumferential distensibility of the veins in low stress range is determined mainly by mechanical characteristics of smooth muscle fibers; (2) the circumferential distensibility of the veins approaches the distensibility of collagen fibers asymptotically in high stress range; (3) longitudinal distensibility of the veins depends on the fractional content of tight elastin fibers.

\section{INERTIAL PRESSURE LOSSES IN PERFUSED HINDLIMB: A REINTERPRETATION OF THE RESULTS OF WHITTAKER AND WINTON}

A. M. Benis, S. Chien, S. Usami and K.-M. JAN

Laboratory of Hemorheology, Department of Physiology, Columbia University College of Physicians and Surgeons, New York, N.Y. 10032

SINCE the classic study of WHITTAKER and WINTON (1933) on the canine hindlimb, the discrepancy between blood viscosity measured in isolated tissue and laboratory viscometers has been attributed to the FåhraeusLindqvist effect. In the present study, Whittaker and Winton's experiments were repeated with the use of freshly isolated limbs and both red cell suspensions and cell-free plasma expanders as perfusates. In addition, limbs fixed in formaldehyde were perfused with Newtonian plasma expanders of known viscosity. In both sets of experiments large discrepancies were consistently found in values of in vivo viscosity for the various cell-free perfusates, an anomaly that cannot be explained on the basis of a Fåhraeus-Lindqvist effect. A likely explanation for the differences between in vivo and in vitro viscosity in the present experiments and in those of previous workers is the occurrence of nonlinear inertial pressure losses.

(Supported by U.S. Army Contract DADA-17-72-C-2115, N.I.H. Research Grant HL-06139 and The Scaife Family Charitable Trusts, Pittsburgh, Pa.)

\section{AN ELECTROVISCOUS EFFECT IN THE RHEOLOGY OF ERYTHROCYTE SUSPENSIONS}

\section{E. BRooks and G. V. F. Seaman}

Polymer Department, Weizmann Institute of Science, Rehovot, Israel and Division of Neurology, University of Or zgon Medical School, Portland, Oregon, 97201

AN IMPORTANT factor in the rheological properties of concentrated erythrocyte suspensions is the degree of cellular aggregation present in the system. Aggregation produced by the addition of dextran to saline suspensions of red cells increases their relative viscosity measured at low rates of shear. Increasing the dextran 
concentration at constant hematocrit alters the degree of aggregation present, and hence the relative viscosity of the suspension. The presence of dextran in the suspending medium also causes an increase in the electrokinetically-measured surface potential of the erythrocytes (zeta potential). This potential is an increasing function of dextran concentration and molecular weight. Above a critical concentration of dextran for each molecular weight studied, and therefore above a critical zeta potential, the erythrocytes disaggregate. The dextran concentration necessary for disaggregation is a strong function of the ionic strength of the suspending medium. This disaggregation seems therefore to be induced by electrostatic interactions between the cells. The degree of aggregation and the transition from aggregation to disaggregation are clearly reflected in the relative viscosities of the cell suspensions measured at low rates of shear. Hence, the available evidence indicates that an electroviscous effect has been observed in this system, the characteristics of which shall be presented.

\title{
AGE-RELATED PROPERTIES OF COLLAGEN SOLUTIONS A VISCOMETRIC TREATMENT
}

\author{
L. C. Cerny, D. M. Stasw and W. Tinelli
}

Utica College of Syracuse University and The Masonic Medical Research Laboratory, Utica, N.Y. 13501

THE DILUTE solution viscosity measurements were performed on collagen obtained from rat tail tendons. The age of the rats varied from 90 to 1000 days. It was found that the viscosity changed with time and could be described with a multiexponential fitting. The time constants were related to the age of the animal from which the collagen was taken. The reversion or "rewinding" experiments indicated that only collagen chains from the "young" rewound. Hybridization showed that the amount of "rewinding" was dependent upon the concentration of the "Young" collagen present.

The intrinsic viscosity of the collagen molecule dropped abruptly at an age of about 250 days. The molecular weight of the change was determined by the ultracentrifuge.

Microcalorimetry measurements were performed to determine the nature and strength of the bonding structure as a function of the age of the collagen.

\section{SOME THEORETICAL CONSIDERATIONS ON ENHANCED DIFFUSION IN FLOWING BLOOD DUE TO RED CELL MOTION}

\author{
Michael M. Chen \\ Department of Mechanical Engineering, New York University, New York, N.Y.
}

IT is known that the tumbling motion of the red cells in shear flow causes considerable enhancement of the diffusion processes for oxygen, carbon dioxide, and particularly platelets. (KelLER, Fedn Proc. 30, 1591, 1971, LeONARD et al., Chem. Eng. Symp. Ser. 66, 59, 1970). Current experimental data, however, are relatively imprecise and cannot delineate the shear rate and hematocrit dependences. This paper seeks to clarify the mechanisms of such enhancement by considering the stochastic processes responsible for it. It is pointed out that uninterrupted, periodic rotation does not contribute to net diffusion, which arises primarily through random processes. Therefore existing theoretical estimates of the effect, showing the diffusion coefficient as proportional to the shear rate and the square of the erythrocyte diameter (KELLER, cited above, PETSCHEK et al., AIAA Paper 70-143, 1970 and CHEN, 24th ACEMB, p. 126, 1971) represent only upper bounds of the diffusion coefficients. More realistic estimates must consider the mechanism which interrupts the periodic orbit motion of the diffusing species around the red cell. A lower bound can be obtained by assuming that Brownian motion is the only mechanism for interrupting the periodicity. This yields a diffusion coefficient which is proportional to the square root of the shear rate. Other randomizing mechanisms include the relative drift in shear field, the collision of red cells, etc. The results yield diffusion coefficients for platelets in the range of $10^{-6}-10^{-7} \mathrm{~cm}^{2} / \mathrm{sec}$, which compares favorably with experimental evidence. Qualitative results on hematocrit dependence suggest that the diffusion coefficient first increases with the hematocrit, but may then decrease at high hematocrits. 


\title{
VARIATIONS OF RETINAL HEMODYNAMICS AS DETECTED BY FLUORESCEIN ANGIOGRAPHY IN BLOOD GLUCOSE: ABNORMALITIES OF DIFFERENT SEVERITY

\author{
P. D. Christacopoulos, D. S. Holsclaw, J. S. Soeldner, H. Shwachman and R. E. Gleason
} \\ E. P. Joslin Research Laboratory and the Childrens Hospital Medical Center, Boston, Massachusetts
}

ReTiNAL fluorescein angiography was performed in 17 normals ( 9 males, 8 females), in 10 offspring of tho diabetic parents ( 7 males, 3 females) and in 7 patients ( 5 males, 2 females) with cystic fibrosis, and overt diabetes mellitus of moderate severity ( 5 requiring insulin) with relatively short duration (32 months mean duration). The transit time of fluorescein was computed in arteries and corresponding veins and the difference in transit time between each pair was employed as the circulation time in seconds (CT).

Seven offspring males showed a shorter mean $\mathrm{CT}$ when compared to seven age-matched normal males $(1.66 \pm 0.8$ vs $2.19 \pm 0.8, P<0.001)$. Furthermore, when comparisons were made between the total groups the offspring also showed a shorter mean CT than normals $(1.53 \pm 0.74$ vs $2.06 \pm 0.87, P<0.001)$.

Dividing the 7 male offspring into those with normal oral glucose tolerance ( 3 prediabetics-PD) and those with abnormal oral glucose tolerance tests (4 asymptomatic chemical diabetics-CD) the mean CT of the CD was shorter than the PD $(1.46 \pm 0.47$ vs $1.95 \pm 0.8, P<0.02)$, and much shorter than the 4 normals of matching age $(1.46 \pm 0.47$ vs $2.20 \pm 0.09, P<0.001)$ while no significant difference in mean CT was seen between the 3 PD and the 3 matching normals $(1.95 \pm 0.8$ vs $2.18 \pm 0.7)$.

The patients with cystic fibrosis and diabetes mellitus showed a longer mean CT than normals $(2.51 \pm 1.85$ vs $2.06 \pm 0.87, P<0.05$ ).

It is concluded that in non-euglycemic asymptomatic genetic chemical diabetics a significantly shorter circulation time is present than in normals, while in overt diabetics after cystic fibrosis despite the shortness of diabetes, the circulation time was much longer than in normals.

Shunts may be the cause of the shorter CT developed under mild abnormalities of carbohydrate metabolism while severe metabolic abnormalities may lead to capillary occlusions and a lengthening of the CT.

\section{A STUDY OF SECONDARY PLATELET-LEUCOCYTE EMBOLISM}

\author{
R. S. CONNELl and Roy. L. SWANK
}

University of Oregon Medical School, Portland, Oregon 97201

PlatelET-LeUCOCYTE aggregates are known to embolize the lungs and produce pathological alterations in the interalveolar septum. Since it has been shown that these emboli when isotopically labelled pass through the lungs after a period of delay, studies were undertaken of other organs which would be secondarily embolizcd. The effects of these migrating aggregates on the cerebral and renal fine structures will be reported.

\section{THE ACTION OF HUMAN RED BLOOD CELLS AND PLATELETS ON VISCOUS RESISTANCE OF PLASMA PROTEIN SYSTEMS}

\section{A. L. COPLEY and R. G. KING}

Hemorrhage and Thrombosis Research Laboratories and Department of Pharmacology, New York Medical College, New York, N.Y. 10029

VIScous resistance was measured of surface layers in whole blood, plasma and fibrinogen solution, employing our modification of the Weissenberg rheogoniometer (Biorheology 7, 1, 1970) with the combined Couette and cone and plate geometry from $10^{3}$ to $10^{-1} \mathrm{sec}^{-1}$. The viscous resistance, $\tau$, of the surface layer is measured by subtracting the torque value in response to shear, obtained with the guard ring fitted, from those secured without the guard ring (Copley, A. L. Biorheology 8, 79, 1971; Copley, A. L. and KInG, R. G. Thrombosis Res. 1, 1, 1972). In whole blood, anticoagulated with EDTA, from healthy human subjects, no difference was found in values obtained with and without the guard ring, indicating that no surface layer was formed. This led us to study the role of red blood cells (RBC) and platelets in the production of polymolecular layers of proteins in whole plasma and in 0.4 per cent fibrinogen solution (in 0.9 per cent sodium chloride). RBC have antiadsorbent action, demonstrated by the $\tau$ values, and thus inhibit or prevent the formation of polymolecular layers of plasma proteins, if added in sufficient concentration. When RBC were added to 
fibrinogen solution in varying concentrations from 5 to 40 per cent, RBC at all concentrations decreased $\tau$ values as compared to that of the control fibrinogen solution. However, when RBC were added in a concentration of 50 per cent to fibrinogen solution, no difference was observed. These measurements show that large concentrations of $\mathrm{RBC}$ are required to prevent the formation of polymolecular layers in 0.4 per cent fibrinogen. The viscous resistance of surface layers of platelet rich plasma was found to be approximately 6 times higher at a shear rate of $10^{-1} \mathrm{sec}^{-1}$ when compared with platelet free plasma from the same blood withdrawal (using EDTA as anticoagulant without blood dilution). Our findings demonstrate that platelets, in contrast to red blood cells, increase markedly the strength of the polymolecular layer of plasma proteins.

(Aided by the Office of Naval Research, United States Navy, Contract N00014-67-A-0449-0002, and the Department of Medicine and Surgery, Veterans Administration, Washington D.C., U.S.A.)

\title{
A FINITE ELEMENT ANALYSIS OF ENDOTHELIAL SHEAR STRESS FOR PULSATILE BLOOD FLOW
}

\author{
Norman Davids and Mohan K. Mani
}

Department of Engineering Mechanics, The Pennsylvania State University

A FINITE-ELEMENT analysis has been developed for determining analytically both the shearing stress distribution over the endothelial surface in the large arteries, and the velocity profiles as well. Our method does not need to assume that the blood flow is laminar; in fact, the rheologic laws of the fluid may be prescribed. It is shown also that the hydrodynamic and mechanical events which occur along the arterial tree are functions of the axial distance and vary sequentially in time, i.e. we have both an "entrance" problem in the fluid sense and a transient problem.

The method begins by subdividing the tube into finite control volumes or elements of simple geometry. In each of these, the current ( $n$-th time step) local velocity components, pressure, and boundary shear stresses are stored. We then consider in turn (a) the force due to local acceleration in the element, (b) the force components due to convective acceleration, (c) the viscous forces, and (d) the pressure forces. These, plus the continuity condition form a set of basic relationships linking the variables from element to element at the $(n+1)$-st time step.

In applications, these relations together with initial and boundary conditions are used directly in a cyclic scheme in the computer. The method is two-dimensional.

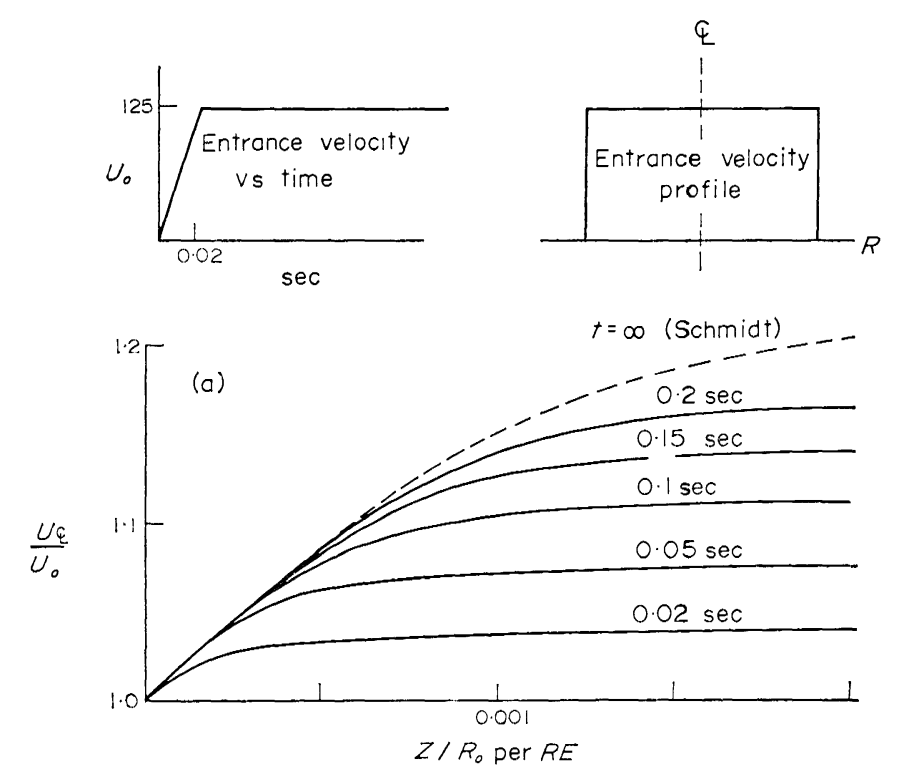

Fig. 1A. Center LiNe Velocity DeVELopment With time. 


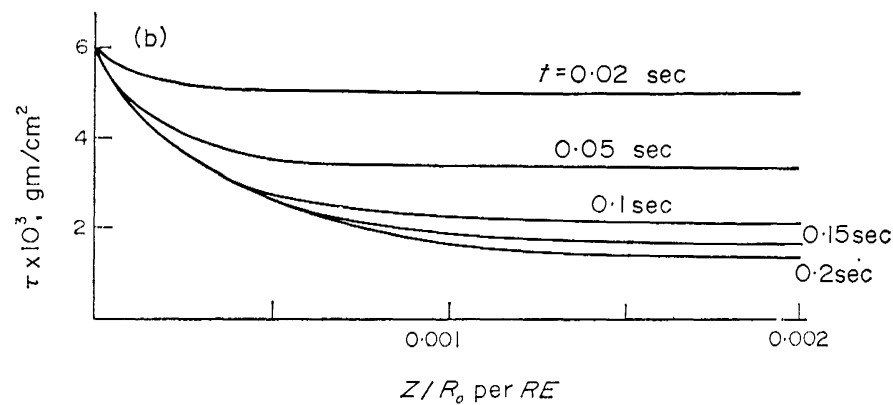

Fig. 1B. WALl Shear StRess DeVelopment with time.

To check the accuracy of the method, the time dependent entry flow problem solved by ATABEK [1] for a circular tube was programmed and close agreement obtained. Figure 1 shows our result for a time dependent entry flow in which the fluid was accelerated uniformly from rest to a value $U_{0}$ and then held constant. We see clearly the time and spatial dependence of the variables.

Results were also obtained for a simulated flow in the ascending aorta using a triangular pulse shape for the cardiac cycle. Wall flexibility effects can also be included in the analysis once a relationship connecting the instantaneous pressure to the radius of the vessel can be established, based on the material properties of the vessel. The calculations made by this analysis are short and efficient in the use of computer time.

\section{REFERENCE}

[1] ATABEK, H. B. J. appl. Math Phys. XIII, 417, 1962.

\section{BLOOD RHEOLOGY AND RHEOLOGY OF BLOOD COAGULATION AS DIAGNOSTIC TOOLS IN STUDY OF MALIGNANT TUMOURS, CARDIOVASCULAR DISEASES AND HAEMATOLOGICAL DISORDERS}

\section{DINTENFASS}

Department of Medicine, University of Sydney, and Haemorheology Unit, Sydney Hospital, Sydney Australia

Viscosity of blood and/or of blood subphases, and viscosity of artificial clots and thrombi, are increased in patients suffering from coronary occlusion, hypertension, peripheral arterial disease, renal failure, lung cancer, intestinal carcinoma, leukaemia, etc. Rheological parameters were determined by means of rotational (cone-in-cone, coaxial rhombospheroid, and hollow cone) viscometers and by capillary and slit glass viscometers; and by means of oscillatory high-amplitude (VFTV) viscometers. A viscosity elevation of any particular blood subphase is related to a specific type of disease. Such particular subphases might be, i.e. concentration or aggregation of red cells or platelets; or increased plasma viscosity; or increased internal viscosity and decreased deformability of the red cells. Some of these effects are amplified by the "inversion phenomenon" in which resistance to flow increases suddenly at certain critical vessel radius, depending on cell rheology. An attempt is made to prepare diagnostic-analytical charts utilizing rheological parameters for a range of diseases.

An application of rheological parameters to diagnosis and study of cardiovascular and malignant diseases relies on two minor and four major tests. The two minor and straightforward tests are the viscosity of plasma and concentration of red cells (haematocrit). The major tests include: (a) evaluation of the internal viscosity of the red cell, and consequent characteristics such as deformation, packing and filtering; (b) estimation of aggregation of red cells; (c) determination of properties of artificial red thrombi of morphology analogous to in vivo thrombi in lower arterial shear range; (d) determination of properties of artificial white thrombi of morphology analogous to in vivo thrombi in higher arterial shear range. (a) The equation for internal viscosity of the red cell, containing a term for Taylor's factor, was proposed in 1968 (DinTENFASS, 1968), although the concepts of internal viscosity of the red cells were covered earlier (DINTENFASS, 1962, 1964-1966). Determination can be carried out by testing viscosity of packed red cells at optimum haematocrits between 80 and 90 per cent. (b) While the low shear rate viscosity of blood is due mainly to the aggregation of red 
cells, the possible non-Newtonian flow of plasma or pseudoplastic characteristics of the interior of the red cells or white cells might play a pronounced role. Therefore, the simple method of estimation of aggregation of red cells is by sedimentation at constant haematocrit, viscosity of plasma being compensated for. Ideal temperature is $37^{\circ} \mathrm{C}$. Westergren tubes are placed in stands in a temperature-controlled bath (no vibration is permissible). (c) Determination of apparent viscosity of artificial red thrombi, their rates of formation, and clotting time, are carried out in variable-frequency thrombo-viscometer (VFTV) as described (DINTENFASS, 1966, 1967; Dintenfass and RuzenberG, 1965, 1967; Rozenberg and Dintenfass, 1965, 1966; Dintenfass and Sharp, 1969; Dintenfass and Stewart, 1968, 1971; DinTenfass and BaUER, 1970).

The key references are as foliows: Dintenfass, L. Angiology 13, 333, 1962; Circulation Res. 14, 1, 1964; J. Lab. Clin. Med. 64, 594, 1964; Exp. Mole. Path. 4, 597, 1965; Circulation Res. 18, 349, 1966; Archs Int. Med. 118, 427, 1966; Nature, Lond. 215, 1099, 1967; Haematologia 1, 387, 1967; Nature, Lond. 219, 956, 1968; Am. Heart J. 77, 139, 1969; Molec. Crystal-Liquid Crystals 8, 101, 1969; J. Roy. College Physicians Lond. 5, 231, 1971; Dintenfass, L. and RozenberG, M. J. Atherosclerosis Res. 5, 276, 1965; Thrombosis et Diathesis Haemorrhagica 17, 112, 1967; DinTENFASS, L. and READ, J. Lancet 1, 570, 1968; DinTENFASs, L. and Stewart, J. H. Thrombosis et Diathesis Haemorrhagica 20, 267, 1968; and 26, 29, 1971; Dintenfass, L. and Sharp, A. Annals Surg. 170, 984, 1969; Dintenfass, L. and Bauer, G. E. Cardiovascular Res. 4, 50, 1970; Rozenberg M. and Dintenfass, L. Haemorrhagica 14, 202, 1965; Nature, Lond. 211, 525, 1966.

This study is being supported by the National Health and Medical Research Council of Australia.

\section{VISCOSITY OF BLOOD IN PATIENTS WITH MYOCARDIAL INFARCTION, HAEMOPHILIA AND THYROID DISEASES. EFFECT OF FIBRINOGEN, ALBUMIN AND GLOBULIN}

\section{Dintenfass, C. D. Forbes and G. P. MCNicol}

Department of Medicine, University of Sydney, and Haemorheology Unit, Sydney Hospital, Sydney, Australia; Department of Medicine (University of Glasgow), Royal Infirmary, Glasgow, Scotland

VIscosIry of anticoagulated blood was studied by means of the coaxial rhombospheroid viscometer; viscosity of plasma was determined in M3 U-tube capillary viscometers. Apparent viscosity of artificial thrombi was studied by means of the variable-frequency thrombo-viscometer. Erythrocyte sedimentation rates were determined at room temperature, all other tests at $37^{\circ} \mathrm{C}$. The subgroups studied included patients with myocardial infarction with and without anticoagulation; Christmas disease and haemophilia A; hyper- and hypothyroid diseases. Of specific interest is a comparison of treatment effects on blood viscosity in infarction and haemophilia. Correlations were studied between fibrinogen concentration and rheological parameters. There

RHEOLOGICAL PARAMETERS IN BLOOD AND THROMBUS FORMATION

\begin{tabular}{lcc}
\hline \multirow{1}{*}{ Parameter } & \multicolumn{2}{c}{ Thyroid diseases } \\
\cline { 2 - 3 } & $\begin{array}{c}\text { Hypo } \\
(\bar{x} / \bar{x} \pm \mathrm{S} . \mathrm{D} .)\end{array}$ & $\begin{array}{c}\text { Hyper } \\
(\bar{x} / \bar{x} \pm \mathrm{S} . \mathrm{D} .)\end{array}$ \\
\hline Plasma viscosity, cp. $37^{\circ} \mathrm{C}$ & $1 \cdot 16$ & $1 \cdot 17$ \\
Blood viscosity, cp. $37^{\circ} \mathrm{C}$ at $144 \mathrm{sec}^{-1}$ & $(1 \cdot 04-1 \cdot 29)$ & $(1 \cdot 08-1 \cdot 26)$ \\
& $3 \cdot 91$ & $3 \cdot 90$ \\
at $216 \mathrm{sec}^{-1}$ & $(3 \cdot 43-4 \cdot 44)$ & $(3 \cdot 39-4 \cdot 47)$ \\
& $3 \cdot 82$ & $3 \cdot 72$ \\
Thrombus viscosity, $37^{\circ} \mathrm{C}$, poises & $(3 \cdot 21-4 \cdot 54)$ & $(3 \cdot 35-4 \cdot 15)$ \\
at $60 \mathrm{c} / \mathrm{min}$ & $6 \cdot 46$ & $6 \cdot 28$ \\
at $180 \mathrm{c} / \mathrm{min}$ & $(4 \cdot 12-10 \cdot 2)$ & $(3 \cdot 14-12 \cdot 7)$ \\
ESR $_{\text {st }} \mathrm{mm} / \mathrm{hr}$, at $20^{\circ} \mathrm{C}$ & $0 \cdot 74$ & $1 \cdot 02$ \\
$\mathrm{ESR}_{\text {st.pl.hc }}$, at $20^{\circ} \mathrm{C}$ & $(0 \cdot 42-1 \cdot 35)$ & $(0 \cdot 43-2 \cdot 41)$ \\
& $30 \cdot 2$ & $20 \cdot 2$ \\
& $(16 \cdot 9-53 \cdot 8)$ & $(11 \cdot 6-34 \cdot 9)$ \\
& $86 \cdot 2$ & $65 \cdot 4$ \\
& $(58 \cdot 2-128)$ & $(27 \cdot 7-154)$ \\
\hline
\end{tabular}


is no correlation between fibrinogen concentration and aggregation of red cells or viscosity of thrombi in myocardial infarction but an excellent correlation exists in haemophilia and thyroid diseases. Values (means and standard deviations) for some parameters, based on log-normal distribution, are contained in the following two tables.

(This study was supported in part by the National Health and Medical Research Council, Australia.)

RHEOLOGICAL PARAMETERS IN BLOOD AND THROMBUS FORMATION

\begin{tabular}{|c|c|c|c|}
\hline Parameter & $\begin{array}{l}\text { Myocard. infarct } \\
(\bar{x} / \bar{x} \pm \text { S.D. })\end{array}$ & $\begin{array}{l}\text { Haemoph A } \\
(\bar{x} / \bar{x} \pm \text { S.D. })\end{array}$ & $\begin{array}{l}\text { Christm. disease } \\
(\bar{x} / \bar{x} \pm \text { S.D. })\end{array}$ \\
\hline Plasma viscosity* $\mathrm{cp}$ & $\begin{array}{c}1 \cdot 24 \\
(1 \cdot 10-1 \cdot 40)\end{array}$ & $\begin{array}{c}1 \cdot 22 \\
(1 \cdot 0-1 \cdot 5)\end{array}$ & $\begin{array}{c}1 \cdot 31 \\
(1 \cdot 14-1 \cdot 5)\end{array}$ \\
\hline $\begin{array}{l}\text { Blood viscosity* cp } \\
\text { at } 144 \mathrm{sec}^{-1} \\
\text { at } 216 \mathrm{sec}^{-1}\end{array}$ & $\begin{array}{c}5 \cdot 32 \\
(4 \cdot 10-6 \cdot 92) \\
4 \cdot 95 \\
(3 \cdot 88-6 \cdot 27)\end{array}$ & $\begin{array}{c}4 \cdot 32 \\
(3 \cdot 8-4 \cdot 9) \\
4 \cdot 09 \\
(3 \cdot 6-4 \cdot 6)\end{array}$ & $\begin{array}{c}3 \cdot 76 \\
(2 \cdot 94-4 \cdot 8) \\
3 \cdot 60 \\
(2 \cdot 94-4 \cdot 4)\end{array}$ \\
\hline $\begin{array}{l}\text { Thrombus viscosity*, poises } \\
\text { at } 60 \mathrm{c} / \mathrm{min} \dagger \\
\text { at } 180 \mathrm{c} / \mathrm{m}_{+}^{+}\end{array}$ & $\begin{array}{c}8 \cdot 07 \\
(3 \cdot 87-17) \\
2 \cdot 21 \\
(1 \cdot 0-4 \cdot 8)\end{array}$ & $\begin{array}{c}5 \cdot 53 \\
(2 \cdot 0-14) \\
1 \cdot 02 \\
(0 \cdot 4-2 \cdot 3)\end{array}$ & $\begin{array}{c}10 \cdot 03 \\
(6 \cdot 9-14) \\
1 \cdot 94 \\
(0 \cdot 9-4 \cdot 0)\end{array}$ \\
\hline $\begin{array}{l}\mathrm{ESR}_{\mathrm{st}} \mathrm{mm} / \mathrm{hr} \S \\
\mathrm{ESR}_{\text {st.pl.he }} \S\end{array}$ & $\begin{array}{l}17 \cdot 2 \\
(8 \cdot 6-48) \\
127 \cdot 7 \\
(55 \cdot 7-294)\end{array}$ & $\begin{array}{l}17 \cdot 2 \\
(4 \cdot 5-66) \\
55 \cdot 0 \\
(13-222)\end{array}$ & $\begin{array}{l}34 \cdot 3 \\
(19-57) \\
74 \cdot 6 \\
(40-139)\end{array}$ \\
\hline
\end{tabular}

* $37^{\circ} \mathrm{C}$. $\dagger$ Mean shear rate $26 \cdot 7 \mathrm{sec}^{-1} . \ddagger$ Mean shear rate $80 \mathrm{sec}^{-1}$. $\S$ At $20^{\circ} \mathrm{C}$.

\title{
INFLUENCE OF ARVIN ON THE FLOW PROPERTIES OF HUMAN BLOOD
}

\author{
A. M. EHRLY \\ Department of Internal Medicine, University of Frankfurt a.M., Germany
}

ARVIN is a fraction of the venom of the Malayan pit viper. Given intravenously in man, it induces a defibrinogenation followed by a reduction in the fibrinogen concentration in blood. A decrease of the fibrinogen concentration in blood, for instance by streptokinase, is known to reduce blood and plasma viscosity and erythrocyte aggregation. Since similar effects could be expected during Arvin therapy, the viscosity of blood and plasma, the erythrocyte aggregation and the flexibiitity of red cells were investigated before and after Arvin injection in patients suffering from peripheral arterial atherosclerosis and ischemia.

Twenty-four hours after starting Arvin therapy, the plasma fibrinogen concentration was nearly unmeasurable. Simultaneously, the viscosity of blood and plasma was decreased and the aggregation of erythrocytes was reduced. Studies with a new 8- $\mu$ filter test system showed no changes in the flexibility of the erythrocytes. Microscopically, the shape of the single cells was unchanged.

Thus, the application of Arvin in patients leads to a decrease in blood viscosity at high and low shear rates and to a reduced erythrocyte aggregation. The red cell membrane is not injured by the venom. The improvement of the flow properties of blood can be maintained over some weeks by daily injections of Arvin. By improving the flow properties of blood, the blood flow will be increased. This flow improvement is not due to a hemodilution; the hematocrit remains unchanged. Improvement of the flow properties of blood seems to be a new concept in the treatment of peripheral ischemic diseases.

\section{REFERENCES}

EHrLY, A. W. Herrenalber Angiologisches Symposium, Mai 1971.

Ehrly, A. M. and LANGe, B. In: Theoretical and Clinical Hemorheology. Proc. of the II International Conference on Hemorheology, Heidelberg 1969 (Edited by Hartert, H. H. and Copley, A. L.) p. 366, Springer, Berlin, 1971.

Ehrly, A. M. and Rossbach, P. 14th International Congress of Hematology, Sao Paulo, 1972. 


\title{
DIURNAL RHYTHM OF HUMAN BLOOD VISCOSITY
}

\author{
A. M. EhrLY and G. JUNG \\ Department of Internal Medicine, University of Frankfurt a.M., Germany
}

THE VISCOSITY of blood is influenced by a number of parameters, such as the hematocrit, fibrinogen concentration, erythrocyte aggregation, red cell flexibility and temperature. Little is known about diurnal variations of blood viscosity.

The experiments were started always in the morning. Young, healthy volunteers were kept in a sitting position for cubital venipuncture. Collection of blood samples started $30 \mathrm{~min}$ thereafter and was repeated at $3 \mathrm{hr}$ intervals throughout the day and night. The blood was anticoagulated with heparin. All volunteers were allowed to eat and drink ad lib. and to follow their work routine. The following parameters were measured: hematocrit, hemoglobin, protein concentration of plasma, viscosity of blood and plasma using an Ostwald- and a Wells-Brookfield viscometer.

In all individuals, blood viscosity exhibited a typical pattern over the 24 -hr range. Thus, it increased in the morning and reached a maximum peak around noon. Lower viscosity values could be measured in the afternoon. A second peak was observed between 8 and 11 p.m. Thereafter, the viscosity decreased continuously to an absolute minimum at $3 \mathrm{a}$ a.m. The other parameters measured, namely hematocrit, hemoglobin, plasma protein concentration and plasma viscosity followed exactly the changing blood viscosity values.

It can be stated from these experiments, that the viscosity of blood in the same individuum is not constant, but rather is fluctuating spontaneously throughout the 24-hr course. The obtained curves seem to show some similarity to well known circadian rhythms. The diurnal viscosity variations can be related to variations in hemoconcentration.

\section{VISCOELASTIC PROPERTIES OF MUCUS}

\author{
N. ELIEZER \\ Polymer Department, Weizmann Institute of Science, Rehovot, Israel
}

IN OUR investigation of the role of mucus in the clearance of respiratory epithelia by the mucociliary system, we have developed a biological model to test the functionality of mucus. This model utilizes palates of frogs, and it has been found that oestrous bovine cervical mucus (BCM) can substitute for the frog's own mucus in maintaining proper clearance. BCM has thus been chosen as a model for epithelial mucus. A study of the viscoelastic behaviour of individual BCM samples has been undertaken, with the aim of characterizing normal mucus rheologically. The instrument used was a concentric cylinder viscoelastometer, in which a sinusoidal torque is applied to the inner cylinder. The phase angle between the applied torque and the resulting displacement of the cylinder has been recorded as function of frequency around three resonance frequencies corresponding to cycle times of $0 \cdot 2,1.5$ and $6 \mathrm{sec}$. Rigidity, viscosity and spectrum of relaxation times have been evaluated under the assumptions of linear viscoelastic behaviour. The variation among samples, the effect of time of storage of the samples and the effects of various manners of treatment of the samples have been studied. The results of these measurements will be presented and discussed with reference to chemical properties of mucus and to some features of the mucocilairy system.

\section{GEOMETRIC PROPERTIES OF INDIVIDUAL RED BLOOD CELL DISCOCYTE-SPHEROCYTE TRANSFORMATIONS}

\section{E. Evans and P. F. LeBLond}

Institut de Pathologie Cellulaire. Hôp. Bicêtre 94-Le Kremlin-Bicêtre, France

THE RHEOLOGICAL properties of blood are dependent upon the shape and deformability of red blood cells. The red blood cell exhibits a broad spectrum of morphological states when subjected to different physical and chemical environments. The mechanisms responsible for the geometrical changes are subtle; therefore, many different theories have been developed to describe the observed shape of the red cell. The obvious commonality between the theories is the requirement for obtaining accurate geometric information of the red cell in various environments. The required accuracy is one percent or better for the characteristic dimensions. Only scanning electron microscopy can provide direct measurements of the red blood cell to this 
accuracy; however, for the scanning electron microscope, the red cells must be fixed and dried before observation, which introduces artifacts. In addition, it is not possible to change the environment of a single cell to quantitate the transformation. Recently, another method has been developed for obtaining the three dimensional geometry with the 1 per cent accuracy using the interference microscope in visible light and computer directed quantitative processing [1].

In this study, we have chosen two particular morphological states, discocyte and spherocyte; the transformation was observed in individual cells. Image holograms (interferograms) were recorded of human red blood cells in two different media. Each cell was exchanged between two chambers by micromanipulation in one chamber, the cell was a discocyte and in the other, a spherocyte. The procedure was cyclic in order to determine the reversibility. The first chamber contained an isotonic, physiological solution with a small percentage of serum albumin to insure the discocytic form. The second chamber contained different spherocytic factors. These included: hypotonic solution for the osmotic sphere; isotonic saline for the spheroechinocyte. The geometry of each cell was obtained from its image hologram by the digital computer process. The results include surface area, volume and dimensions for each cell.

\section{REFERENCE}

[1] Evans, E. A. J. Optical Soc. Am. 61, 991, 1971.

\section{FLOW AND DEFORMATION IN CONCENTRATED EMULSIONS: LIQUID DROPS AS MODELS OF ERYTHROCYTES}

\section{F. J. Gauthier, H. L. Goldsmith and S. G. Mason}

Departments of Chemistry and Experimental Medicine, McGill University, Montreal, Canada

Deformable liquid drops have been used by some authors to model the shear deformation of isolated erythrocytes. In whole blood, however, deformation of cells results from the combined effects of shear and particle crowding. Hence, a study of droplets in concentrated monodisperse emulsions undergoing tube flow was undertaken since it might yield useful information about erythrocyte flow behavior at normal hematocrits under comparable conditions of flow. Suspensions 14-37 per cent by volume of $0 \cdot 1 \mathrm{~cm}$ radius polyglycol oil drops in silicone oils were observed in $1 \mathrm{~cm}$ radius glass tubes at mean linear flow rates from 0.004 to $0.1 \mathrm{~cm} / \mathrm{sec}$ (Reynolds numbers $<10^{-2}$ ).

As previously found in suspensions of rigid spheres, the velocity distributions at a given volume flow rate were blunted at concentrations above 25 per cent with partial plug flow developing in the core of the tube. However, the extent of the plug flow at a given concentration and particle size was smaller in the emulsions and decreased with increasing flow rate, and at a given flow rate, with increasing suspending phase viscosity. When the emulsions were broken up by stirring, the mean drop radius decreased to $0.005 \mathrm{~cm}$ and the velocity profiles were parabolic at all flow rates.

The deformed drops migrated away from the tube wall at rates which fluctuated as particles collided with each other, and decreased to zero in the core of the tube. Here, in the particle-crowded suspension, the drop paths were subject to sideways fluctuations and the particles were distorted as they squeezed past each other.

Comparison with data obtained in human ghost cell and red cell suspensions showed that at a given value of the shear deformation parameter, the degree of blunting of the velocity profile was similar in the different systems.

\section{FLOW AND DEFORMATION IN HUMAN BLOOD: ERYTHROCYTES IN GHOST CELL SUSPENSIONS}

\section{H. L. GOLDSMITH}

Department of Experimental Medicine, McGill University, Montreal, Canada

IN WHOLE blood, the movements of individual erythrocytes are greatly influenced by the presence of large numbers of other corpuscles. Working with tracer human red cells in transparent plasma suspensions of reconstituted biconcave ghost cells, it was shown that particle crowding in tube flow results in: (i) velocity distributions blunted from the parabolic; (ii) particle paths which exhibit erratic radial displacements in directions normal to the flow; and (iii) deformation of the cells to a degree not attributable to shear alone. 
This paper describes experiments designed to explore these phenomena in greater detail using 10-70 per cent ghost cell suspensions flowing in tubes of $30-70 \mu$ radius at mean velocities of $0.01-0.6 \mathrm{~cm} / \mathrm{sec}$. As with concentrated emulsions, the degree of blunting of the velocity profiles decreased with increasing flow rate and decreasing concentration. But the parabolic distribution was never completely restored suggesting that both particle interaction forces and, at low concentrations, inward migration from the wall resulting in twophase flow, were significant.

By analogy with Brownian motion diffusion coefficients, dispersion coefficients based on the mean square red cell radial displacements over small time intervals were calculated. At wall shear rates of $20 \mathrm{sec}^{-1}$, these ranged from $3 \times 10^{-8}$ to $1.5 \times 10^{-7} \mathrm{~cm}^{2} / \mathrm{sec}$, depending on radial position and concentration, thus approaching the value for the free diffusion coefficient of molecules such as serum albumin. The effect of particle size on radial dispersion was investigated using $2 \mu$ latex spheres. At a given cell concentration these exhibited much greater radial movements, even being able to pass through the core of partial plug flow. Detailed studies of the core revealed the existence of small relative cell axial velocities and radial fluctuations, probably due to the transmission of disturbances from the periphery.

\title{
THE RHEOLOGY OF MESOPHASES FORMED BY PURE ESTERS OF CHOLESTEROL AND THEIR BLENDS
}

\section{Charles W. Griffen and Roger S. Porter}

Polymer Science and Engineering University of Massachusetts, Amherst, Massachusetts

RHEOLOGY is one of the two main aspects of mesophases, i.e. liquid crystals. It is surprising then that so few studies have been made on defined mesophase systems. In this work, we have developed viscosity measurements as a function of temperature and shear from 0.03 to $30 \mathrm{sec}^{-1}$ on the pure aliphatic esters of cholesterol and their blends. Measurements were made in the isotropic state and at temperature conditions for formation of cholesteric and smectic mesophases. The principal measurements were made on the pure acetate and myristate esters and their blends. A Weissenberg Rheogoniometer was used. Rheological tests were made for mesophase and texture transitions as well as for the orientation dependence of viscosity. These steady state viscosity tests have also been compared with optical microscope and calorimetry studies on the same systems. The results are interpreted in terms of the structures and phase diagrams for these mesophase systems.

\section{HEMORHEOLOGY IN THE BONE MARROW}

\author{
Joseph F. Gross and CARL GAZley, JR.
}

The Rand Corporation, 1700 Main Street, Santa Monica, California 90406

THE BONE marrow is an important embryonoid tissue dispersed throughout the body in the bone cavities and is responsible for the production of the formed elements in the blood. The inaccessibility and complexity of the marrow tissue have prevented a complete description of both its morphology and its physiological and physical behavior. In recent years, however, the success of cytotoxic agents in inducing long-term remissions in myeloid tumours has stimulated interest in the bone marrow and, in particular, in the effect of chemotherapeutic agents on the physiology of normal marrow as well as on that of the pathologically altered tissue.

Animal studies have shown that the marrow microvasculature is quite different from that in other tissues, both in structure and dynamic behavior. In fact, the blood flow dynamics are probably coupled quite closely with the physiological processes which occur (e.g. production of red blood cells) and with the changing structure of the extravascular tissue. A brief review is given of the important morphological elements in the marrow microvasculature and of the general features of the microcirculatory system. The implications of the hemodynamics for the choice of the appropriate hemorheological model are discussed.

A model is proposed that reflects some of the basic characteristics of the blood flow in the marrow and describes the coupling between the pressure drop-flow behavior and the structural properties of the extravascular tissue. Comparison of the model results with experimental data taken in cat and rabbit femurs shows qualitative agreement. Extension of the model to include more details of the morphology using a finite element analysis is described. 


\title{
RHEO-STIMULATION. A NEW METHOD AND ITS APPLICATION IN THE ASSAY OF CLOTTING PROCESS AND FACTOR XIII
}

\author{
H. HARTERT
}

Saar-Universität and Städt. Krankenhaus, Med. Department, Kaiserslautern, West Germany

FLow of gas or liquid is accompanied by electroviscous effects, which in the case of blood may govern physiological and pathological processes. The reproduction and observation of these effects in vitro is made possible by the employment of a precession movement of the clip in the thrombelastograph, superimposed and the regular cup movement. The result is a very strong effect on blood clotting, revealing a novel type of clot formation, which is different from that occuring in a motionless test tube. It cannot be demonstrated if the cup is only shaken instead of moving it circular and continuously in the procession way. Ciotting in the Rheosimulator takes place as an abrupt phenomenon. The correlation between the electroviscous effects on molecular order in flowing blood and the strong facilitation of fibrin formation becomes apparent by the fact, that lack of clotting factor XIII coincides with lack of the abrupt clotting phenomenon.

\section{THIXOTROPY OF HUMAN BLOOD}

\section{R. Huang, N. Siskovic, R. W. J. Robertson, H. H. Wang and P. Orosz, JR.}

Department of Chemical Engineering and Chemistry, Newark College of Engineering, Newark, N.J. 07012

From the currently accepted definition of thixotropy, one of the characteristics is the flow curve of thixotropic fluids showing a hysteresis loop. The time-dependent (torque-decay) behavior of whole human blood has been obtained by different investigators. With a Model 16 Weissenberg Rheogoniometer modified with a continuously variable speed drive, we recorded the hysteresis loop of whole human blood on a Monigraphic $2000 \mathrm{X}-\mathrm{Y}$ Recorder. Thus it establishes that blood is a thixotropic fluid as many other suspension systems. Experiments were made on the blood of ten apparently healthy male human donors and the results are presented. A rheological equation of state developed from irreversible thermodynamics with five lumped parameter was employed to represent the thixotropy of each blood sample. From experimentally obtained flow curve (hysteresis loop) and the torque-decay curve, these lumped parameters in the rheological equation were calculated by a digital computer via the technique of non-linear least squares parameter estimation. These thixotropic parameters can be used not only to represent the rheological property of the blood of each donor, but also to serve as the characteristics quantitatively of the blood from different donors. The parameters in the rheological equation include the equilibrium value of a molecular arrangement parameter of non-aggregated erythrocytes, the rate constant of dissociation of the aggregated form of erythrocytes under a shear stress, the order of the dissociation reaction, the yield stress and a coefficient which relates the shear stress and the molecular arrangement parameter.

\section{INTERPRÉTATION MOLÉCULAIRE DE LA VISCOSITÉ DES SOLUTIONS AQUEUSES TRÈS CONCENTRÉES DES BIOPOLYMÈRES}

\section{Joly, D. Bourgorn et E. Volf}

Service de Biophysique, Institut Pasteur, Paris

LE CAS étudié est celui des solutions aqueuses d'un dextrane de poids moléculaire moyen 150.000 dans le domaine de concentration de 10-60 pour cent. Les mesures de viscosité sont effectuées au moyen d'un rhéogoniomètre de Weissenberg dans une gamme de vitesses de cisaillement allant de $1,8 \times 10^{-2} \mathrm{sec}^{-1}$ à $1,8 \times 10^{2} \mathrm{sec}^{-1}$.

L'étude de la viscosité en fonction de la concentration permet de distinguer des domaines contigus dans lesquels le logarithme de la viscosité varie linéairement avec la concentration.

Pour interpréter l'ensemble des résultats on propose un modèle de structure des solutions concentrées de dextrane dans lequel on fait jouer un rôle important à l'organisation des molécules d'eau entourant les résidus D-glucopyranose successifs de la macromolécule ainsi qu'aux liaisons entre ces molécules.

A partir de ce modèle, on tente de rendre compte de la variation de la viscosité apparente des solutions concentrées de dextrane en fonction de la vitesse de cisaillement et de la concentration. On applique pour 
cela les théories de la viscosité de Eyring et Ree, de Mack, et de Goodeve et Gillespie. La comparaison des résultats ainsi obtenus avec ceux de l'expérience aide à préciser le mécanisme moléculaire de l'écoulement des solutions aqueuses très concentrées du biopolymère.

L'état de l'eau jouant un rôle fondamental dans le comportement rhéologique de ces solutions, cet état a été caractérisé par l'étude de la dispersion diélectrique des solutions dans le même intervalle de concentration en dextrane. Cette étude a été faite dans les bandes de fréquence 7,5-10 GHz et 0,5-2,5 MHz. Elle a permis d'évaluer l'importance relative de l'eau libre et de l'eau de solvatation dans les solutions macromoléculaires considérées.

\title{
AN ESTIMATE OF RED CELL MEMBRANE STRAIN IN BLOOD FLOW
}

\section{KenNeth A. KLINe}

\author{
Wayne State University, Detroit, Michigan 48202
}

\begin{abstract}
AN eSTIMATE of red cell membrane strain is derived based on a liquid drop model of blood rheology. In steady rectilinear shear flow the strain is tensile and compressive in alternate quadrants, and the maximum value of strain is a function of shear rate and rheological properties of the red cell and suspending fluid. The wall shear stress is related to maximum membrane strain, and predictions of theory are compared to experimental results on hemolysis of Champion, North, Coakley and Williams. It appears membrane strain energy at hemolysis is a function of the ratio of cell to suspending fluid viscosity, so long as membrane properties are unaltered by the nature of the suspending fluid. This is seen to be in agreement with G. I. Taylor's results on the burst of liquid drops.
\end{abstract}

\section{ESTIMATES OF RED CELL MEMBRANE STRAIN IN OSCILLATORY BLOOD FLOWS}

\section{KeNNETH A. KLINE}

Wayne State University, Detroit, Michigan 48202

THE ESTIMATE of red cell membrane strain as obtained based on a liquid drop model of blood rheology is applied to cases of oscillatory blood flows. Estimated red cell membrane strains in oscillatory uniform shear fields are calculated and discussed with respect to the experimental observations on hemolysis reported by Rooney and Williams, Hughes and Nyborg. Red cell membrane strains are also estimated for oscillatory, nonuniform shear fields. An estimate of red cell membrane strain, as a function of distance of the cell from the tube center, is given for the case of pulsatile blood flow in a tube.

\section{SHEAR RATE DEPENDENT BLOOD COAGULATION: RHEOLOGY OF PLATELETS IN COAGULATION OF PLATELET-RICH PLASMA (PRP)}

\section{H. J. Klose, H. SChMid-SChÖNbein and H. BReChtelsbauer}

Department of Physiology, University of Munich, German Federal Republic

IT HAS been shown repeatedly that the formation of platelet plugs in vivo requires a minimum of flow [1]. The influence of the flow regime on the coagulation time, the morphology and consistency of the blood coagulum have been studied extensively by DinTENFASS [2]. Direct microscopic observation showed that the acceleration of coagulation in whole blood at high shear rates was accompanied by shear dependent platelet aggregation [3]. A more detailed study of the role of platelets in the coagulation process of PRP was executed in cone plate chamber $\left(0 \cdot 7-700 \mathrm{sec}^{-1}\right)$ made of siliconized plexiglass. Platelet aggregation (by photometry) and the onset of plasma coagulation (by strain gauge) were monitored independently. Experiments were performed in steady state and oscillatory viscometric flow and with continuously changing (increasing and decreasing) shear rate. The chamber could be thermostated between 2 and $37^{\circ} \mathrm{C}$. Fresh unanticoagulated PRP was obtained from chilled human blood, centrifuged at $500 \mathrm{~g}$, and transferred to the pre-chilled apparatus. The experiment itself was started by switching temperature to $37^{\circ} \mathrm{C}$. (1) The coagulation time in PRP was inversely proportional to the shear rate; the highest coagulation times occurring in stasis. (2) At high shear, the aggregation of platelets consistently preceded the fibrin formation, while at low shear, the two phenomena 
occurred simultaneously. (3) Coagular produced under high shear consisted of irregular clumps of plateletleucocyte aggregates, surrounded by coarse fibrin-strands (white coagula) low shear clots consisted of fibrin-strands with single platelets or small platelet aggregates distributed regularly throughout. These results indicate that, (a) the flow regime simulating arterial thrombosis (high shear rates) is dominated by completely different series of coagulation processes compared to those at simulated venous thrombosis (low shear rates), (b) the platelets are activated by shear alone without the addition of extraneous reagents, (c) shear induced platelet aggregation-by some, as yet unidentified, process-activates the fibrin formation.

\section{REFERENCES}

[1] Begent, N. and Brown, G. V. R. Nature, Lond. 227, 926, 1970.

[2] Dintenfass, L. Blood Microrheology. Butterworths, London, 1971.

[3] Schmid-Schönbein, H., Goldstone, J. and Wells, R. E. Proc. IV Int. Congress of Pharmacol., Vol. I., 1969.

\section{SUSPENSION OF MICROCAPSULES AS A MODEL OF BLOOD}

\section{T. Kondo and B. TAMAMUSH}

Faculty of Pharmaceutical Sciences, Science University of Tokyo, and Nezu Chemical Institute, Musashi University, Tokyo, Japan

POLYLYSINE-PHTHALAMIDE microcapsules containing aqueous hemoglobin solution are prepared by interfacial polycondensation reactions between lysine and terephthaloyl chloride and then dispersed in physiological salt solution with or without other solute substances. With such microcapsule suspensions thus prepared, particle size distribution, electrophoretic mobility, flocculation and flow properties (shear rateshear force, viscosity-shear force relationships etc.) are measured. On the basis of the experimental data the possibility of using such suspension as a model of blood is discussed.

\section{INFLUENCE DE SIX SUBSTITUTS DU PLASMA ET DES SOLUTIONS D'HÉMOGLOBINE SUR LA VISCOSITÉ PLASMATIQUE}

\section{A. Larcan, J. F. Stoltz et S. Gaillard}

Groupe de Recherches Hémorhéologiques, Centre Régional de Transfusion et Service de Réanimation, C.H.U. 54-Nancy, France

LES MODIFICATIONS rhéologiques induites par les substituts du plasma ont suscité jusqu'à ce jour de nombreux travaux.

A l'aide d'un viscosimètre à cylindres coaxiaux, les auteurs ont cependant envisagé l'étude comparative de l'influence de six de ceux-ci sur la viscosité plasmatique aussi bien in vitro qu' in vivo.

Les substituts étudiés ont été deux Dextrans de poids moléculaire de 40.000 et 80.000 (Rhéomacrodex et Dextran clin.), trois gélatines fluides modifiées (Plasmagel ionique et normal, Haemacel) et une PVP (Subtosan). Les auteurs ont de plus étudié in vitro uniquement la viscosité des solutions d'hémoglobine à pouvoir de transport d'oxygène constant.

En ce qui concerne les études in vitro, celles-ci ont été réalisées par mélange de plasma citraté avec le substitut étudié.

Quant à l'étudie in vivo, elle est réalisée par étude de la viscosité plasmatique avant et après perfusion de 1 ou 2 flacons de substituts. Les incidences rhéologiques sont alors envisagées.

\section{APPROCHES THÉORIQUES ET EXPÉRIMENTALES DE LA ZONE D'INFLUENCE AUX EMBRANCHEMENTS DU LIT VASCULAIRE}

M. Lefort, E. Wackenheim, J. F. Stoltz et A. Larcan

Groupe de Recherches Hémorhéologiques, Centre Régional de Transfusion et Service de Réanimation, C.H.U. 54-Nancy, France

LE PROBLÈME de la répartition des débits aux embranchements vasculaires reste un des problèmes les moins étudiés de l'hémodynamique sanguine.

Dans ce travail, les auteurs envisagent une approche de ce problème à l'aide d'un modèle tridimensionnel

віо. 9/3-C 
ce qui leur permet une visualisation ainsi qu'une approche théorique du phénomène. Dans tous les cas, le fluide a été l'eau et la visualisation a été obtenue à l'aide de l'émission de fluoresceine.

Ils montrent en particulier que l'approximation de la zone d'influence par un arc de cercle est en bon accord avec leurs résultats expérimentaux.

D'autre part, les expériences des auteurs mettent en évidence l'existence de zones mortes en aval de la bifurcation. Ces zones pourraient alors être des endroits privilégiés de dépot.

Du point de vue théorique, le calcul montre l'existence d'une relation de proportionnalité entre le débit dans la branche principale $\left(Q_{1}\right)$ et le débit dans la zone secondaire $\left(Q_{3}\right)$. Avec les hypothèses d'un fluide Newtonien le facteur de proportionnalité dépend uniquement de deux paramètres (rayon de la zone d'influence et position de celle-ci par rapport à l'axe du vaisseau).

\section{BIORHEOLOGICAL ASPECTS OF COLONIC ACTIVITY}

\section{P. S. Lykoudis, P. D. Patel and P. Picologlou}

School of Aeronautics, Astronautics and Engineering Sciences, Purdue University, Lafayette, Indiana 47906

BASED on our work on peristalsis [1] in the upper urinary tract, we are presently studying some biorheological aspects of the motility of the large intestine (colon). The large intestine is capable of a variety of movements described and classified in the medical literature [2]. In order to carry out an analysis for the intraluminal pressure and velocity fields associated with such movements, the rheological properties of the colonic contents (chyme) were needed. A survey of the literature revealed that no such information was available.

An experiment involving viscometric measurements on the human feces was designed. The measurements were performed on a suitably built tube viscometer. Preliminary results indicate that the human feces behave rheologically as a power law fiuid, namely $\tau=k(\mathrm{~d} u / \mathrm{d} y)^{n}$. For the average rates of strain prevailing in the human colon (as calculated from an order of magnitude analysis), the exponent $n$ was found to remain essentially constant and approximately equal to 0.25 although the consistency parameter $k$ varied widely with different samples.

Assuming that chyme follows the same constitutive relation as do feces, the mathematical analysis is carried out for general $k$ and $n$ for two different kinds of colonic movement; (a) peristalsis, and (b) segmental radial and longitudinal contraction and dilatation. The theoretical results provide us with a correlation between the kinematics of the boundary of the colon, its geometry, the rheological properties of chyme and the intraluminal pressure.

\section{REFERENCES}

[1] Lykoudis, P. S. In Urodynamics (Edited by Bayarsky, S.) Proceedings of the Workshop on "Hydrodynamics of the Upper Urinary Tract". Academic Press, New York, 1971.

[2] RICHIE, J. A. Gut 9, 442-502, 1968.

\section{APPARENT VISCOSITY OF NATIVE HUMAN BLOOD AT VARIOUS HYDROSTATIC PRESSURES}

\section{J. L. Martin, R. M. Jacobs, R. S. Marshall and A. L. Copley}

Department of Mechanical Engineering, Newark College of Engineering, Newark N.J. 07201; Hemorrhage and Thrombosis Research Laboratories and Department of Pharmacology, New York Medical College, New York, N.Y. 10029

THE APPARENT viscosity of native human blood, i.e. whole blood, not treated with anticoagulants, and secured from healthy human subjects, has been determined at room temperature and at pressures of $17 \cdot 7 \times 10^{3}, 194 \times 10^{3}, 371 \times 10^{3}$ and $548 \times 10^{3} \mathrm{~kg} / \mathrm{m}^{2}$. A falling projectile viscometer was designed and built for this study. The viscometer consisted of three approximately right circular cylindrical chambers, subject to distinct pressures, placed vertically, and three inserted projectiles. The unavoidable venturi shape of the projectiles necessitated a number of tests with each standard fluid used for calibration and required careful screening of photographs to eliminate instrument artefacts due to misalignment of the projectiles during fall. The projectiles were clamped and released by a set of bar magnets. Calibration was accomplished by filling the chambers with standard fluids, the known viscosities of which were slightly above and below the expected apparent viscosity of whole human blood. The projectile motion was photographed with stroboscope light 
and a curve of viscosity vs velocity for each chamber was plotted. All three chambers were photographed simultaneously. Apparent viscosity determinations were made by subjecting three portions of a single blood sample, drawn by venipuncture, to the indicated pressures in each of the chambers of the instrument. The apparent viscosity, which had an average of $8 \mathrm{cP}$, showed no correlation with hydrostatic pressures of $548 \times 10^{3} \mathrm{~kg} / \mathrm{m}^{2}$. No discernible effect of hydrostatic pressure was found on the viscosity of whole human blood extra vivum.

(Aided by the Office of Naval Research, United States Navy, Contract N00014-71A-0124, Washington D.C.)

MODEL EXPERIMENT ON THE POST-STENOTIC DILATATION IN BLOOD VESSEL

\author{
Y. Matunobu and M. Arakawa
}

Department of Physics, Keio University, Yokohama, Japan

AMONG the numerous phenomena about blood circulation, the post-stenotic dilatation may be one of the most interesting problems from the fluid-dynamical point of view. It provides a new aspect of fluid motion occurring in the region bounded by the vessel wall. The post-stenotic dilatation has been considered to be produced by purely dynamical origin, for example, E. Holman succeeded in producing it on a rubber tubing by using an artificial circulatory system with a pump (J. Thrac. Surg. 28, 109, 1954). However, the relation between the flow pattern produced by the stenosis and the stress distribution over the vessel wall is not still obvious, so that we cannot say about quantitative nature of the stenotic effect. Our main concern is to clarify this point in terms of the fluid-dynamical languages. In order to visualize the stenotic effect clearly, we make a transparent conduit with rectangular cross section and fit in a barrier of several types to intercept the liquid flow. Then, we allow starch to be settled down evenly on the wall in the conduit filled with the liquid. Thus, we can observe how the surface of starch is eroded by the liquid streaming out of the stenotic region, which makes possible to predict the stress distribution approximately. Second, by drawing a model of stenosis together with a camera in the liquid at rest, the flow pattern behind the stenosis is observed, providing reasonable interpretation of the conduit experiment.

\title{
IN VIVO HEMORHEOLOGY EMPLOYING OUTFLOW VISCOMETRIC TECHNIQUES
}

\author{
Herbert J. Meiselman, Wallace G. Frasher and Harold Wayland
}

University of Southern California School of Medicine, Los Angeles, California; LACHA-USC Cardiovascular Research Laboratory, L.A. County-USC Medical Center, Los Angeles, California; California Institute of Technology, Pasadena, California 90033

THE CONTINUING interest in blood rheology is, we feel, a direct result of increasing interest in quantitatively understanding the behavior of blood as it flows through the living circulatory system as well as through engineering devices. The majority of existing literature reports in this area involve ex vivum hemorheology and thus the attendant questions regarding shed blood artifacts. In order to obtain quantitative rheological measurements on normal or intentionally modified native dog blood, an in vivo viscometer utilizing outflow techniques has been employed. The basic measurement assembly consists of a $200 \mu$ capillary tube branching at right angles to a chronic, externalized carotid artery-jugular vein shunt; flow rate through this capillary is controlled by a variable speed syringe pump.

Experimental programs and results to be reported include: (1) Effect of anticoagulants. Acute heparinization has no effect on the rheological properties of dog blood; (2) Influence of hematocrit variations. Over the range of hematocrits studied ( $20-50$ per cent), dog blood can be described as a pseudoplastic, non-Newtonian suspension, with apparent viscosity decreasing as either shear rate increases or hematocrit decreases; (3) Effect of acute fibrination. The plasma concentration of fibrinogen, per se, does not alter the rheology of dog blood; plasma viscosity alterations are of significant importance; (4) Hemodilution with low molecular weight dextran (LMWD). When comparisons are made at equal hematocrits, our results indicate an increased apparent viscosity of blood when using LMWD vis-à-vis saline; generally lower values of apparent relative viscosity were obtained for LMWD.

(Supported in part by NIH grants HE 08977 and HE 11153.) 


\section{MÉTHODES D’ÉTUDE DE LA RHÉOLOGIE DES EXPECTORATIONS

\author{
Cl. Molina, J. M. Aiache, J. Brun et J. Cl. Cheminat
}

Laboratoire de la Clinique de Pneumo-Phtisiologie de Clermont-Ferrand

L'EXPECTORATION est un milieu hétérogene, non Newtonien, pseudo-plastique et thixotrope.

Nous avons réalisé, depuis 3 ans, à la Clinique Pneumo-Phtisiologique de Clermont-Fd, plus de 15.000 déterminations sur le mucus fibrillaire des expectorations débarrassées de la phase aqueuse grace aux microviscosimètres cône-plateau qui permettent d'obtenir des résultats fidèles et reproductibles.

Les mesures sont réalisées selon un protocole défini (température constante, vitesses de rotation variables etc.) et rapportées sur un graphique quotidien pour chaque malade.

Nous avons pu mettre en corrélation ces résultats rhéologiques avec les modifications histologiques et bio-chimiques, du mucus bronchique.

L'étude rhéologique est un moyen fidèle, objectif d'apprécier l'action des médications fluidifiantes dans le traitement des bronchopneumopathies.

Une étude statistique nous a permis de constater que l'association mucolytique-antibiotique est significativement plus efficace que le traitement par mucolytiques ou antibiotiques seuls.

\section{BLOOD FLOW AND WALL CHARGE}

\section{Robert OsSoff and Stanley Charm}

New England Enzyme Center, Tufts University Medical School, Boston, Massachusetts 02111

BLOOD flow through negatively charged capillary tubing (about $700 \mu$ dia.) showed significant decreases in pressure loss as compared with positive or neutral tubing.

The flow in neutral and cationic tubing behaved as would be expected from viscosity measurements taken in a cone and plate viscometer. In negatively charged tubing the apparent viscosity was 15 per cent less for hematocrits of 45 and 27 per cent less for hematocrits of 60 . However, for hematocrits of 30 or less the cell suspension in the negatively charged tube has the same apparent viscosity as it did in neutral and positive tubing and in the cone and plate viscometer.

The negatively charged tubing repels cells from the wall causing a greater marginal layer than in similar positive or neutral tubing, resulting in a lowering of apparent viscosity. However at low hematocrits, the cell migration from the wall is sufficiently great in all these tubes that the effect of wall charge on the cells was negligible.

It is generally considered that vessel walls have a negative charge. Hence to relate "ex vivo" flow studies with "in vivo" systems, consideration must be given to this parameter.

\section{THE INFLUENCE OF FLOW RATE AND HAEMATOCRIT ON THE LOCATION OF THE ZONE OF MAXIMUM CELL CONCENTRATION IN BLOOD FLOWING DOWN A CAPILLARY SLIT}

\section{A. A. Palmer and W. H. Betts}

Kanematsu Memorial Institute, Sydney, Australia

WHEN blood of low cell concentration (haematocrit) was made to flow down a capillary slit, a region of maximum cell concentration developed in a zone between the wall and the axial plane; this phenomenon is analogous to the tubular pinch effect which has been observed by GoLDSMITH [1] in capillary tubes of circular cross-section. At lower flow rates or with suspensions of higher haematocrit the maximum cell concentration was found at the axial plane.

Method. Fresh citrated human blood, adjusted to the required haematocrit by centrifugation and removal of red cells, was made to flow vertically down a capillary slit of short axis $25 \mu$ and length $1 \mathrm{~cm}$, ending in 5 slitlike branches. The volume and haematocrit of the fluid issuing from each branch were measured. These data gave the cell concentration in each of 5 zones across the short axis of the slit. The shear rate at the wall and the width and positions of the zones were calculated on the assumption that the velocity profile across the short axis of the slit was parabolic, since the suspensions were dilute. 
Results. With suspensions ranging from 0.7 to 10 per cent haematocrit, at wall shear rates exceeding $6000 /$ $\mathrm{sec}$ the zone of maximum cell concentration, was displaced from the axial plane by about $0 \cdot 25 r$ (where $r$ is the short semi-axis). With suspensions of 14 per cent haematocrit, or greater, the zone of maximum cell concentration was located at the axial plane at all rates up to the highest tested, 17,600/sec. The upper pair of histograms show that with a suspension of 0.6 per cent haematocrit, as the wall shear rate was increased from 1280 to 16,600 the zone of maximum cell concentration moved away from the axis. The lower histograms illustrate the lack of effect of a comparable change of shear rate with a suspension of 14 per cent haematocrit.

\section{REFERENCE}

[1] Goldsmith, H. L. Fedn Proc. 30, 1578, 1971.
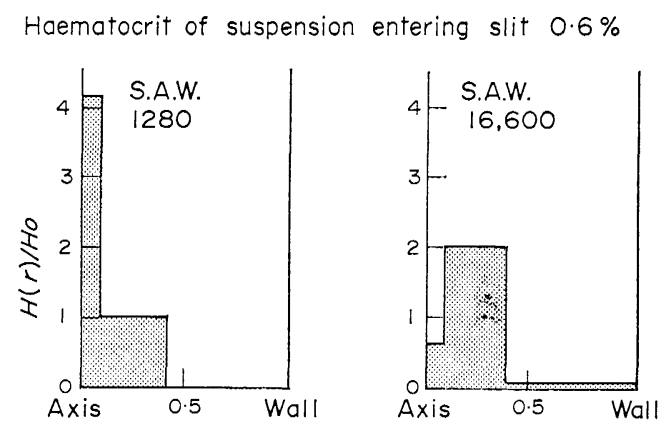

Haematocrit of suspension entering slit $14 \%$
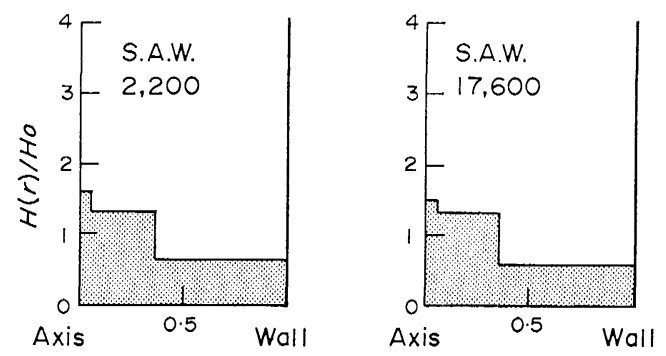

Fig. 1. VOLUME CONCENTRATION DISTRIBUTION OF RED CELLS ACROSS THE SHORT AXIS OF A $25 \mu$ SLIT, MEASURED $1 \mathrm{~cm}$ DOWNSTREAM FROM THE RESERVOIR. $H(r) / H o$, ratio of zone haematocrit to reservoir haematocrit.

S.A.W.--Shear at Wall.

\section{DAS THIXOTROPE VERHALTEN VON HIRNGEWEBE BEI SAUERSTOFFMANGEL}

\section{G. QUADBECK}

\section{Institut für Pathochemie und Allgemeine Neurochemie der Universität Heidelberg}

HiRnGEWebe von Menschen, wie solches von Ratten, zeigt ein ausgeprägtes thixotropes Verhalten. Die Viskositätszunahme eines frisch bereiteten Hirnhomogenates ist beim Menschen, wie bei der Ratte altersabhängig. Sie steigt mit dem Lebensalter an und erreicht beim Menschen bei 20-30 Jahren, bei der Ratte mit etwa 12 Monaten ihr Maximum. Die Ausgangsviskosität eines frisch hergestellten Hirnhomogenates ist vom Lebensalter weitgehend unabhängig und steigt beim Menschen erst ab 60 Jahre steil an. An Katzen konnte gezeigt werden, daß eine commotio cerebri das Hirngewebe so verändert, daß die Viskositätszunahme eines nach dem Trauma hergestellten Homogenates deutlich verzögert ist. Es ist zu vermuten, daß bei der Commotio cerebri eine Auflockerung der protoplasmatischen Strukturen eintritt, wodurch eine Reorganisation der Gel-Strukturen verzögert wird. Die Frage, warum im fortgeschrittenen Alter das kolloidale Verhalten 
von Hirnhomogenaten sich wesentlich von dem unterscheidet, was man bei Hirnhomogenaten von Jugendlichen findet, ist nicht leicht zu beantworten. Da die Stoffwechselaktivität des menschlichen Gehirns im höheren Lebensalter deutlich absinkt, wurde geprüft, ob eine Herabsetzung der cerebralen Stoffwechselaktivität das kolloidale Verhalten von Hirnhomogenaten beeinflußt. An Ratten, die für wenige Minuten einem Sauerstoffmangel ausgesetzt waren konnte gezeigt werden, da $\beta$ die Viskositätszunahme im Hirnhomogenat deutlich gesteigert war. Wurden aber die Ratten für mehrere Stunden einem Sauerstoffmangel ausgesetzt, so war nicht nur die Ausgangsviskosität der Hirnhomogenate deutlich erhöht, sondern gleichzeitig war auch die Viskositätszunahme deutlich vermindert. Die Hirnhomogenate die ser durch Sauerstoffmangel geschädigten Ratten verhielten sich analog wie solche von alten Menschen. Die Befunde lassen vermuten, da $\beta$ beim Hirngewebe zwischen kolloidalem Verhalten und Stoffwechselaktivität ein Zusammenhang besteht.

\title{
CORRELATIONS BETWEEN MICRO- AND MACRO-CIRCULATORY CHANGES DURING TREATMENT OF PERIPHERAL VASCULAR DISEASES WITH XANTHYL NICOTINATE
}

\section{H. S. Rozov and Eli Davis}

Microcirculation Research Laboratory, Hadassah University Hospital, Jerusalem

EIGHT normals and 55 patients with mainly occlusive peripheral vascular disease were examined and treated during a period of 18 months. Apart from usual clinical tests, comparat-oscillometry, oscillography, electronic dermalthermometry, pulsometry, petechiometry, and ergometric tests were carried out. Blood viscosities at different shear rates, fibrinogen, hematocrit, E.S.R., and cholesterol were evaluated. Slit lamp observation and microphotography of the bulbar conjunctiva of the eye was used to evaluate changes in sludge, stasis, stasis pools, flow velocity, patency of capillary networks, V.A. ratios and ischaemia.

A correlation was found between improvements in flow and microcirculatory parameters on the one hand, and the clinical and ergometric results and macrocirculatory haemodynamic balance. Both sets of parameters were dependent in a majority of cases upon a "threshold" dosage of xanthyl nicotinate of the order of $600 \mathrm{mg} / \mathrm{oz}$ three times daily.

There was a correlation between improvement of flow in ischaemic limbs and that in ischaemia of the bulbar conjunctival microcirculation. Observed acceleration in small vessel blood flow and reduction in arteriolar and capillary erythrocyte aggregation were accompanied by the appearance of previously-unobserved capillary networks in formerly ischaemic areas. Erythrocyte flow in capillaries previously inaccessible may be due to changes in their elasticity and deformability, and to reduction in whole blood viscosity. Xanthyl nicotinate is reported to increase A.T.P. levels in erythrocytes, and thus to restore their deformability; this and increase in flow velocity may explain some effects seen.

\section{COMPARATIVE MICRORHEOLOGY OF BLOOD: EFFECT OF DESAGGREGATION, RED CELL ORIENTATION AND RED CELL FLUIDITY ON SHEAR THINNING OF BLOOD IN VARIOUS SPECIES}

\author{
H. SChMid-Schönbein, J. Van Gosen and H. J. Klose
}

Department of Physiology, University of Munich, German Federal Republic

WITH a few exceptions [1], most workers in blood rheology have tacitly assumed that blood behaves like other suspensions of rigid particles. The deformability of the red cells was only recently shown to be the main factor in the shear thinning behavior of the blood, a behavior hitherto ascribed to hydrodynamic desaggregation or phase separation. Evidence suggesting a fluid drop like transition of human erythrocytes under shear was presented:

(1) ellipsoid deformation and orientation of cells in flow, major axis parallel to flow direction [2, 4];

(2) tank tread like rotation of red cell membrane around the cell content $[2,4]$ and migration of red cells along shear stress gradients;

(3) relative apparent blood viscosity inversely related to plasma viscosity [ 2 and many other authors];

(4) fluidity of packed cells [1,2 and others].

To further elucidate this concept, human, bovine and amphibian red cells were studied by viscometry (Wells-Brookfield, Weissenberg Rheogoniometer) as well as in a transparent cone and plate (chamber plate in counterrotation to cone) microscopically in flow $(625 \times$ magnification in indicent, dark field and phase contrast illumination). Bovine blood does not form aggregates (even at the lowest $\gamma$ ) nor does it follow 
Casson's equation at low shear rates. Shear thinning viscosity in bovine blood is based exclusively on fluid drop like transition with increasing shear, relative apparent viscosity being inversely related to plasma viscosity. Nucleated ellipsoid amphibia cells show orientation at low rates of shear, which does not, however, increase with shear. Relative apparent viscosity is higher than in mammals, falls less with shear and is not a function of plasma viscosity. In human red cells, the fluid drop like transition requires much smaller shear stresses $\left(0 \cdot 1-0 \cdot 5 \mathrm{dyn} / \mathrm{cm}^{2}\right)$ than hydrodynamic desaggregation $\left(2-20 \mathrm{dyn} / \mathrm{cm}^{2}\right)$. Cell deformation into irregular prolate ellipsoids can be demonstrated in blood of normal hematocrit. In artificial media (viscous dextran solutions) the cells are transformed into regular prolate ellipsoids (no dimples). The direct microcinematographic proof of membrane rotation obviates speculations about the liquid crystalline nature of the membrane or the intracellular hemoglobin solution [1].

\title{
REFERENCES
}

[1] Dintenfass, L. Blood Microrheology, Butterworths, London, 1971.

[2] Schmid-Schönbein, H. and Wells, R. E. Ergebnisse der Physiologie, Vol. 63, 1971.

[3] Chien, S. In: Hemodilution, Theoretical Basis and Clinical Application. Karger, Basel, 1972.

[4] Goldsmith, H. Fedn Proc. 30, 1578, 1971.

\section{VISCOELASTIC BEHAVIOR OF CONDUIT ARTERIES}

\section{G. SHARMA}

The Pennsylvania State University, University Park, Pennsylvania

RECENT research has indicated that the mechanical factors associated with the blood flow in the arteries and the resulting distensibility produced by the blood pressure have considerable influence on the nature of heart disease in human beings. Due to the pulsatile character of blood flow, the internal pressure on the arterial wall is also pulsatile with a fluctuating component of pressure superimposed on a mean component of pressure. Depending upon the local blood pressure, arteries undergo various amounts of distensibility which brings about large local deformation. It has been established that this large deformation behavior leads to a nonlinear relationship between the stress and strain tensor of the arterial wall. In addition, the pulsatile nature of the blood pressure leads to a viscoelastic response in the arterial wall.

This paper is concerned with the experimental investigation for the rheological behavior of conduit arteries in vitro. The large deformation behavior of the steer aorta was studied by subjecting rectangular specimens to various combinations of biaxial states of stress and measuring the stretch ratios using the rectangular grids printed on the surface of the specimens. A nontoxic dye, Nile blue A, was used to print grids on the specimens. From the experimental data strain energy density function, representing the energy stored per unit volume of the undeformed material was determined for various parts of the thoracic aorta. Results indicate that the thoracic aorta displays non-isotropic mechanical behavior and the stiffness of the aorta progressively increases from the upper thoracic aorta to the lower thoracic aorta.

The paper describes, in addition, the experimental study for the dynamic viscoelastic behavior of the arteries under sinusoidal uniaxial stresses at various frequencies ranging from 2 to $20 \mathrm{c} / \mathrm{s}$. Storage and loss modulus values for the above frequency range were evaluated for various magnitudes of mean strains that occur under physiological range of mean blood pressure. The dynamic properties were determined using a specially developed apparatus that is also described in this paper.

\section{VISCOSITÄTSMESSUNGEN AN BLUT UND PLASMA VON HUNDEN (TEMPERATUR-VISCOSITÄTSVERHALTEN, INFUSION).}

\author{
F. Spinelli und Ch. Meier
}

MIT HILFE eines Rotations-Rheometers und einem nach dem Couette-Prinzip arbeitenden Spezial-Messystem für kleine Substanzmengen $(0,35 \mathrm{ml})$ werden rheologische Messungen en Blut und Plasma von Hunden durchgeführt. Es wird angestrebt, das Fliessverhalten bis zu einem Schergefälle von $D=0,003 \mathrm{sec}^{-1}$ und bei verschiedenen Spaltverhältnissen zu bestimmen. Mit den Messungen werden dabei die beiden folgenden Probleme verfolgt: 
1. Bei Narkose wird die Körpertemperatur infolge Aufhebung der Temperatur-Regulierung zum Sinken gebracht. Das Viscositäts-Temperaturverhalten, welches mit einer separaten Blutprobe bestimmt worden ist, wird mit den rheologischen Messungen der einzelnen Blutproben, die bei entsprechenden Temperaturen direkt vom Körper entnommen und gemessen werden, verglichen. Es soll damit abgeklärt werden, ob der Ansteig der Viscosität des Blutes im lebenden Tier infolge abfallender Körpertemperatur durch due Narkosesich gleich verhält wie bei der der mit separaten Blutproben bestimmten Viscositäts--TemperaturKurve. Die Messungen werden sowohl am Vollblut als auch am Plasma von venösem und arteriellem Blut durchgeführt.

2. Die Veränderung des Fliessverhaltens von Vollblut und Plasma an venösem und arteriellem Blut wird bestimmt nach Zugabe einer isotonen Kochsalzlösung bei einer Infusionsgeschwindigkeit von 10 prozendes Körpergewichtes in einer halben Stunde. Während der ganzen Infusionseinwirkung wird die Kört pertemperatur mittels eines Thermofühlers im Darm kontrolliert und über eine Infrarotlampe konstant gehalten.

Die Viscositäts-Messunngen werden über ein grosses Schergefällespektrum vorgenommen. Damit soll festgelegt werden, innerhalb welchem Schergefällebereich eindeutig feststellbare Unterschiede der Viscosität von venösem und arteriellem Blut und Plasma gemessen werden können.

\title{
MODIFICATIONS DE LA CHARGE SUPERFICIELLE ET DES PROPRIÉTÉS RHÉOLOGIQUES DU GLOBULE ROUGE PAR ACTION DES ANTICORPS DE TYPE INCOMPLET. INFLUENCE SUR LA VISCOSITÉ SANGUINE
}

\author{
J. F. Stoltz, A. Larcan, F. Streiff, C. Vigneron, B. Genetet, C. Raffoux et S. Gaillard
}

Groupe de Recherches Hémorhéologiques, Centre Régional de Transfusion et Service de Réanimation, C.H.U. 54-Nancy, France

L'ÉTUDE rapportée par les auteurs envisage les modifications de trois paramètres hémorhéologiques entraînées par la présence d'anticorps de type incomplet sur la membrane érythrocytaire (Maladie hémolytique, anticorps de type incomplet).

C'est ainsi que la charge de surface étudiée par la technique d'électrophorèse en phase liquide montre que: -la mobilité d'hématies suspendues en eau physiologique n'est pas modifiée par la présence d'anticorps incomplet;

-la mobilité des hématies suspendues dans un milieu eau physiologique + albumine bovine est différente pour les globules revêtus d'anticorps que pour les hématies normales.

D'autre part, il est admis aujourd'hui que l'étude de la fragilité des hématies est, en première approximation, une approche des propriétés rhéologiques de cet élément. Les auteurs montrent alors que dans le cas des anticorps incomplets, la présence de ceux-ci sur la membrane érythrocytaire entraine une fragilisation de celle-ci due vraisemblablement à une plus grande rigidité de l'hématie.

La mesure comparative, à l'hematocrite constant, de la viscosité de suspensions d'hématies met alors en évidence une variation de celle-ci pour les hématies sensibilisées.

\section{CLINICAL INVESTIGATIONS WITH AN IMPROVED FILTRATION TEST (FT) ON RED BLOOD CELL (RBC) RHEOLOGY IN HAEMOLYTIC ANAEMIAS (HA)}

\section{P. Teitel, G. Galeczki, A. Xenakis and I. Marcu}

Laboratory of Biochenistry and Radioactive Isotopes, Center of Haematology, Bucharest 2 (str. C. Caracaș, 2-8) Rumania

A THEORY of the Erythrocyte Filterability Test (N.R. Fr. Hémat. 7, 195, 1967) was developed. The filtered volumes of a Newtonian fluid depending exponentially upon time, a plot of log per cent non-filtered volumes vs. time, termed "filtration curve" $(\mathrm{FC})$ is a straight line. The Hagen-Poiseuille law was applied to the flow through one individual "equivalent" narrow tube (ENT) in the filter, whereby the non-stationary terms $(\Delta \bar{P}$ and $\bar{Q})$ were substituted with exponential expressions specifying their dependence upon time. Utilizin $\xi$ the parameter "half-time of filtration" $\left(T_{\frac{1}{2}}^{\frac{1}{2}}\right)$, the Hagen-Poiseuille equation cancelled out to

$$
\eta=T_{2}^{1}\left[\frac{n R^{4}}{4 L} \cdot \frac{\rho g}{\ln 2}\right]
$$


where the term in brackets is a constant. Validation of the FT as a polymicroviscometer was made with aqueous polyvinylpyrollidone solutions of known viscosities (Ostwald). The shear stresses in each ENT being transient, a FC allows defining the sample rheology, any departure from linearity indicating nonNewtonian character. A simple means to estimate it is suggested in terms of the ratio of $T_{2}^{1}$ and $T_{1}^{\frac{1}{4}}$.

A number of over 400 samples of normal and pathological RBC was studied, yielding following patterns of FC: (1) non-linear shear-thinning, for normal RBC; (2) non-linear shear-thinning with arrest of filtration (resulting from "rheological obstruction" of the ENT); (3) bimodal; (4) linear; and (5) non-linear shearthickening. Patterns $2-5$ were found in various HA.

Clinical studies were made in 250 patients. RBC from typical constitutional HA were Newtonian and the increased bulk viscosity of their concentrated suspensions (Hcrt $>95 \%)$ was correlated $(r>0.98)$ with a shortened life span and increased splenic sequestration (chromium-51 determinations). for the abnormal non-Newtonian RBC, the proposition is made to utilize $T_{2}^{1}$ as an "equivalent average viscosity" (EAV) for the set predetermined conditions of the FT. The EAV is compounding both the "apparent" viscosities and the extent of the departure from Newtonian behaviour. Albeit with a lesser accuracy, the EAV is useful on a routine basis for the indirect clinical estimation of $\mathrm{RBC}$ survival $(r \cong 0.8)$ and rheological factors of splenic sequestration.

$A$. Non-stationary terms substituted in the Hagen-Poiseuille equation:

$$
\begin{gathered}
\tilde{P}(t)=\frac{1}{3} \rho g^{3} \sqrt{\left(\frac{9 V_{o}}{\pi}\right) \times l^{-3} K \rho g t} \\
\bar{Q}_{\mathrm{ENT}}(t)=\left[\frac{1}{3 \pi} \rho g \frac{V_{o} K}{n\left(\frac{9 V_{o}}{\pi}\right)^{\frac{2}{3}}}\right] \times l^{-3 K \rho g t}
\end{gathered}
$$

B. Typical Filtration Curves (FC)

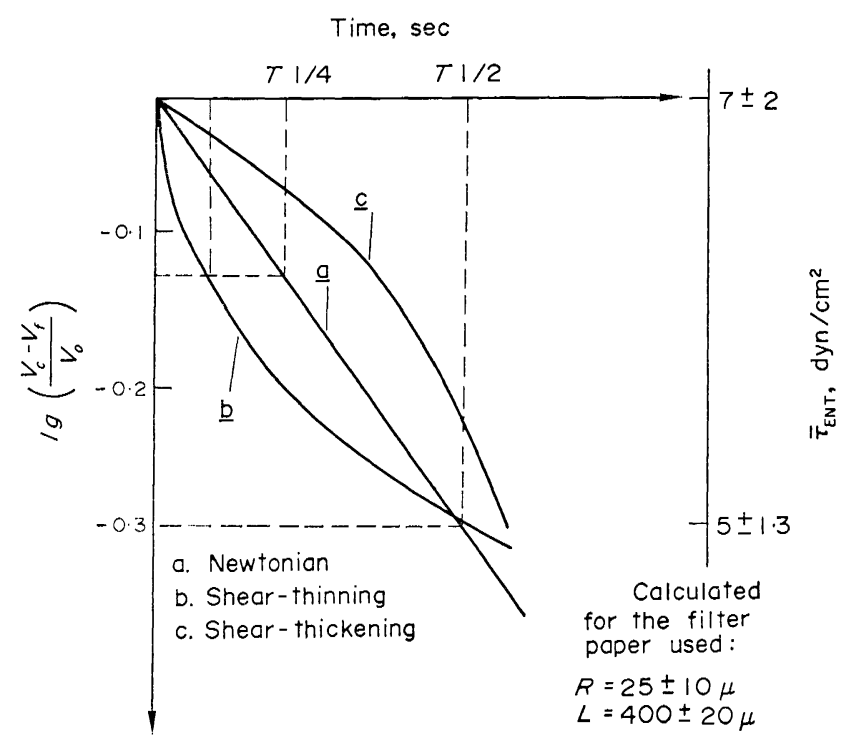

SCHEME 1.

\section{FREQUENCY AND SHEAR RATE DEPENDENCE OF VISCOELASTICITY OF HUMAN BLOOD}

\section{George B. Thurston}

Biomedical Engineering and Electronics Research Center, College of Engineering, The University of Texas at Austin, Austin, Texas 78712

MEASUREMENTS show that human blood possesses viscoelastic properties which are significant in the time scale of the normal pulsation rate. These properties are dependent upon both the frequency and amplitude of 
shear rate in oscillatory flow. The character of the amplitude dependence indicates that blood has a structure which becomes disrupted at high shear rates. These effects are revealed from studies of oscillatory flow in rigid circular tubes. Using the theory for flow of a viscoelastic fluid (Thurston, G. B. J. Acoustical Soc. Am. 32, 210, 1960; ibid. 33, 109, 1961) measured values of the pressure gradient and volume velocity are used to determine mean shearing stress and velocity gradient in the tube. The stress is resolved into a viscous component $\tau^{\prime}$ which is in phase with the velocity gradient $G$ and an elastic component $\tau^{\prime \prime}$ which is $90^{\circ}$ out of phase. While both components are significant with whole blood, the blood plasma alone exhibits only a significant viscous component. At small velocity gradients, both $\tau^{\prime}$ and $\tau^{\prime \prime}$ are directly proportional to $G$. At higher gradients this linear relationship is lost. For blood of 50 per cent hematocrit this change of character occurs near $G=1 \mathrm{sec}^{-1}$ at a frequency of $1 \mathrm{~Hz}$. At high gradients, $G>60 \mathrm{sec}^{-1}, \tau^{\prime}$ again approximates a linear dependence upon $G$ while $\tau^{\prime \prime}$ tends to become limited and hence insensitive to $G$. At low gradients where linear conditions exist, the ratio of shear stress to velocity gradient gives the complex coefficient of viscosity of the blood, $\eta^{*}$. Measurements of $\eta^{*}$ over a wide frequency range show a general decrease of $\eta^{*}$ with increasing frequency in the range from 0.1 to $100 \mathrm{~Hz}$. Thus, a wide spectrum of relaxation times is in evidence.

\title{
SHEAR DEFORMATION OF RED CELL GHOSTS
}

\section{SHUNichi UsAmi and SHU CHIEN}

Laboratory of Hemorheology, Department of Physiology, Columbia University Coliege of Physicians and Surgeons, New York, N.Y. 10032

Deformability of red cells is a major cause of the decrease in blood viscosity at high shear rates. In an attempt to investigate the influences of the internal viscosity $\left(\eta_{i}\right)$ and external viscosity $\left(\eta_{0}\right)$ on red cell deformation, hemoglobin-poor red cell membrane ghosts were prepared by gradual osmotic hemolysis from the blood of healthy human donors. The red cell ghosts were suspended in media with different external viscosities at various cell concentrations, and the viscosity was measured with a coaxial cylinder viscometer at $37^{\circ} \mathrm{C}$. At high shear rates, the relative apparent viscosity of ghost suspensions $\left(\eta_{r}\right)$ at a constant $\eta_{i}$ decreased with increasing $\eta_{o}$. At low shear rates, however, $\eta_{r}$ of ghost suspensions was essentially constant when $\eta_{o}$, was varied. Comparison of the data of red cell ghosts and normal red cells was complicated by the fact that the tensile property of the cell membrane had been altered during ghost preparation. Our results support the concept that shear deformation of red cells is a function of the viscosity ratio between the external medium and the intracellular hemoglobin fluid $\left(\eta_{0} / \eta_{i}\right)$.

(Supported by U.S. Army Contract DADA-17-72-C-2115, N.I.H. Research Grant HL-06139 and The Scaife Family Charitable Trusts, Pittsburgh, Pa.)

\section{THE EFFECT OF REDUCED SALINITY ON RED CELL AGGREGATION: A MODEL OF AGGREGATE FORMATION}

\author{
E. VOLGER, H.-J. KLOSE and H. SCHMID-SCHÖNBEIN
}

Department of Physiology, University of Munich, German Federal Republic

RED CELL aggregation has conventionally been attributed exclusively to the action of certain plasma proteins (e.g. fibrinogen, $a 2$-macroglobulin). It can also be produced experimentally by gelatine, poly-vinyl-pyrolydin and high molecular weight dextran $(>60,000)$ while low molecular weight dextran has no such effect. All factors changing the normal shape and deformability of red cells abolish or hinder the aggregate formation, a mechanism explaining desaggregating effects of chemical agents.

A factor hitherto not appreciated is the salinity of the medium. Dialysing plasma against isotonic mannitol solutions reduces the salinity [as measured by the specific conductivity $x(\mathrm{msec})]$ and significantly increases its viscosity. Lowering the salinity of RC suspensions in plasma or serum produces first decreasing aggregate formation until at a conductivity below $1 \mathrm{~ms}$ a sharp increase of RC aggregate and clump formation takes place. RC in isotonic solutions of albumin or dextran 40 at normal salinity ( $5 \mathrm{~ms}$ at 45 per cent $\mathrm{Hct}$ ) do not show any aggregation. However, below $1 \mathrm{~ms}$ too, shear resistant aggregates are formed depending on the colloid concentration. Bovine blood, incapable of aggregate formation in normal plasma, also does form aggregates when the salinity is reduced below $0.5 \mathrm{~ms}$. Here, however, the aggregation is weaker than in human blood under identical conditions. 
Irrespective of possible changes in the cell surface charge, this clearly shows that red cell aggregation can greatly be enhanced despite unchanged plasma protein composition. This effect is likely to be due to physicochemical alterations due to molecular association of colloids with decreasing ionic strength. The resulting molecular aggregates have enhanced adhesive action. Our results lead to the hypothesis that RCA is not caused by a specific binding process of distinct proteins (agglomerins, 1) but is rather the consequence of a non-specific interaction between any adhesive plasma proteins of minimum molecular weight and the cell surface.

\section{REFERENCE}

RUHENSTROHT-BAuer, G. Klin-Wschr. 44, 531, 1966.

\section{HYDRODYNAMIC DISRUPTION OF HUMAN ERYTHROCYTES}

\section{A. R. Williams}

Department of Anatomy, University of Manchester, Manchester M13 9PL

COAGULANT-FREE fresh adult human blood was diluted 200 -fold with isotonic or hypotonic buffered saline pH $7 \cdot 4$ containing glucose $(0-60 \mathrm{mM})$ and $10 \% w / v$ Dextran 500 which increased the viscosity of the suspension to about $20 \mathrm{c} / \mathrm{s}$. Dextran is a non-penetrating thickener which has been added so that the cells can be subjected to large hydrodynamic shear stresses at reasonably low velocity gradients $\left(10^{3}-10^{4} \mathrm{sec}^{-1}\right)$. Aliquots of this suspension were subjected to known hydrodynamic shear stresses at various temperatures between

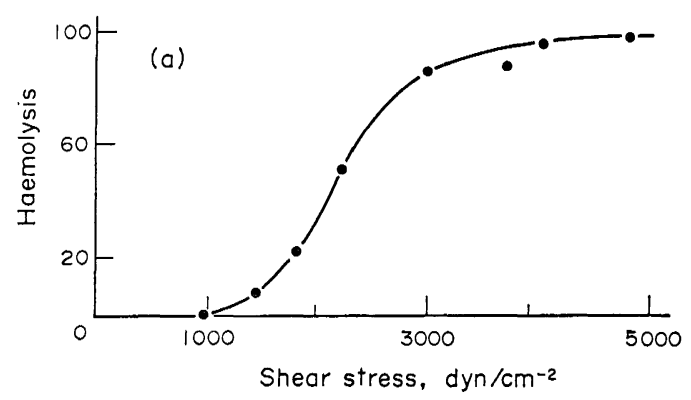

Fig. 1A. HAEMOLYSIS IN HYPOTONIC ( 0.54 per cent) ISALINE CONTAINING 13 per cent DEXTRAN AFTER 5 min SHEAR AT $25^{\circ} \mathrm{C}$ (NO GLUCOSE).

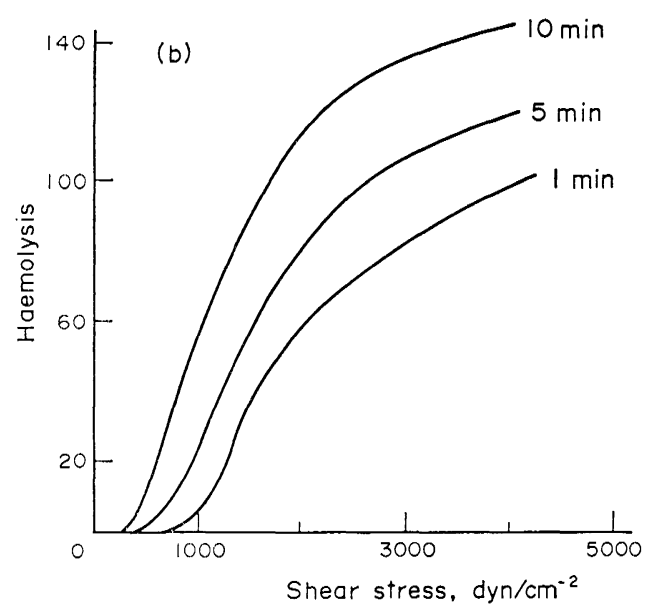

Fig. 1B. HAEMOLYSIS IN HYPOTONIC ( 0.9 per cent) SALINE CONTAINING $60 \mathrm{mM}$ GLUCOSE AND 10 per cent Dextran at $25^{\circ} \mathrm{C}$. 
the rotating cone and stationary plate of a Ferranti-Shirley viscometer. Erythrocytes sphered in hypotonic saline burst when stretched beyond their elastic (or viscoelastic) limit, whereas bi-concave cells in isotonic medium fragment to produce a characteristic distribution of haemoglobin-filled microspheres. The viscoelastic properties of the erythrocyte membrane result in both stress and time thresholds, and in a family of curves relating haemoglobin release and/or microsphere production with both the magnitude and duration of the applied shear stress.

\section{DER PROTEINGEHALT IM PERIVASALEN BINDEGEWEBE ALS FAKTOR DER PERMEABILITÄT}

\section{SieGfried Witte}

Diakonissenkrankenhaus, Karlsruhe-Rüppurr, German Federal Republic

StRÖMUNGSVORGÄNGE sind bei Permeabilitätsphänomenen mehrfach beteiligt. Wir haben besonders die folgenden Pertialvorgänge vitalmikroskopisch untersucht: die Permeabilität der Kapillarwand, die Flüssigkeitsbewegungen im perivasalen Bindegewebe und die Lymphbildung. Alle diese Strömungsvorgänge werden vom Proteingehalt beeinflußt. Es handelt sich um die Proteinkonzentration im zirkulierenden Blutplasma, im perivasalen Bindegewebe und in der Lymphe. Wir haben eine Methode entwickelt, mit der man den Proteingehalt dieser Kompartimente in vivo bestimmen kann. Die Messungen erfolgen vitalmikrospektrophotometrisch in einzelnen Gefäßen der terminalen Strombahn, am Bindegewebe in verschiedener Entfernung von Blutgefäßen und in Lymphgefäßen. Dann wurde die Proteinkonzentration experimentell modifiziert durch intravenöse Injektionen von Protein lösungen oder physiologischer Kochsalzlösung. Hierdurch ändern sich die erwähnten Permeabilitätsverhältnisse. Die Proteinkonzentration im perivasalen Bindegewebe nimmt zu oder ab. Wir erfassen somit Bewegungen von Wasser und Proteinen als Komponenten der Biorheologie des Bindegewebes. 